\title{
Developmental Diagnostics Working Group
}

National Cancer Institute

\section{Source}

National Cancer Institute. Developmental Diagnostics Working Group. NCI Thesaurus.

Code C19522.

Mission and Organization: To identify broad scientific opportunities that would enable the National Cancer Institute to develop tests that will allow treatment choice to be based on the fundamental properties of a tumor cell. 